\title{
Digestive tract morphometry and breast muscle microstructure in spent breeder ducks maintained in a conservation programme of genetic resources
}

\author{
Dariusz Kokoszyński ${ }^{1}$, Mohamed Saleh ${ }^{2}$, Zenon Bernacki ${ }^{1}$, Marek Kotowicz ${ }^{3}$, Małgorzata Sobczak ${ }^{3}$, \\ Joanna Żochowska-Kujawska ${ }^{3}$, and Kamil Stęczny ${ }^{1}$ \\ ${ }^{1}$ Department of Animal Sciences, Faculty of Animal Breeding and Biology, \\ UTP University of Science and Technology, Mazowiecka 28, 85-084 Bydgoszcz, Poland \\ ${ }^{2}$ Department of Poultry and Animal Production, Faculty of Agriculture, \\ Sohag University, Street Nasser City, 82524 Sohag, Egypt \\ ${ }^{3}$ Department of Meat Science, Faculty of Food Sciences and Fisheries, \\ West Pomeranian University of Technology, Kazimierza Królewicza 4, 71-550 Szczecin, Poland
}

Correspondence: Dariusz Kokoszyński (kokoszynski@gmail.com)

Received: 22 June 2018 - Revised: 23 August 2018 - Accepted: 31 August 2018 - Published: 30 September 2018

\begin{abstract}
The objective of this study was to compare three genetic groups of ducks: P9 (French Pekin), K2 (bred from wild mallards - Anas platyrhynchos L. and Pekin duck), and KhO1 (hybrid of Khaki Campbell drake and Orpington Fauve duck) after two breeding seasons for body weight and length, length of intestine and its segments, percentage of other internal organs, and breast muscle microstructure. The study used 60 ducks, 20 birds (10 males and 10 females) from each genetic group. At 110 weeks of age, P9 ducks exhibited significantly $(p<0.05)$ greater body weight and length, and length of intestine and its segments (except for colon length) compared to $\mathrm{K} 2$ and $\mathrm{KhO} 1$ ducks. KhO1 ducks had significantly shorter jejunum and ileum compared to $\mathrm{K} 2$ birds. The lighter $\mathrm{K} 2$ and $\mathrm{KhO} 1$ ducks had significantly greater relative length of intestine and its segments. In P9 ducks, liver, heart, and gizzard were heavier and spleen percentage in body weight significantly lower than in $\mathrm{K} 2$ and $\mathrm{KhO} 1$ birds. KhO1 ducks had a significantly higher percentage of proventriculus compared to the other duck groups. The different genetic origins of the ducks had no effect on microstructural characteristics of $m$. pectoralis superficialis except for perimysium and endomysium thickness. Our study provided information about differences in the digestive tract morphometry and breast muscle microstructure of ducks from three genetic groups after two reproductive seasons, which are maintained in a conservation programme of genetic resources in Poland.
\end{abstract}

\section{Introduction}

The structure of the digestive tract is indicative of the rate of digestion. Intestinal length in mature hens and turkeys is 5-6 times, and in ducks and geese 4-5 times, as high as their body length. In other monogastric farm animals (pigs and horses), the intestine to body length ratio is much higher, $25: 1$ and $20: 1$, respectively (Langenfeld, 1992). Research results (Szczepańczyk et al., 2000; Hassouna, 2001) show that individual birds differ considerably in the weight, length, and diameter of the intestine and its segments. This variation is determined mainly by genetic (species, breed, line, hybrid) and environmental factors, especially the amount and type of ingested food as well as thermal conditions. Other factors affecting intestinal development are body size, sex, age, health status, and physiological status of birds (King et al., 2000; Szczepańczyk et al., 2000; Wasilewski et al., 2015). Applegate et al. (2005) found jejunum and ileum to be 3.7fold heavier and 1.6-fold longer in fast-growing Pekin ducks aged 7 weeks than in almost 2-fold lighter turkey poults of the same age. Kasperska et al. (2012) observed that relative length $\left(\mathrm{cm} 100^{-1} \mathrm{~g} \mathrm{BW}\right)$ of the small intestine, caecum, and 
total intestine decreased significantly with the age of guinea fowl. In turn, Szczepańczyk et al. (2000) noted that birds consuming animal origin food had a relatively shorter small intestine in relation to body length compared to seed eaters, and that the energy concentration had an effect on the amount of ingested feed.

Due to its functions such as food content storage, digestion, and absorption of nutrients from food, the digestive tract has a considerable impact on animal body growth and development as well as on chemical composition, nutritive and dietetic value, and other muscle tissue quality traits.

Muscle fibre microstructure, in particular the percentage of white and red fibres, their diameter and contraction, the amount and distribution of the connective tissue, and the amount of its different fractions (epimysium, perimysium) largely determine meat tenderness, which is considered the most important trait encouraging the consumption of meat (Elminowska-Wenda and Szpinda, 2011). Muscle fibre structure is genetically determined and varies according to poultry species (Kissling, 1977). Breed, age, diet, health, housing system, and physical activity also affect the diameter and percentage of white and red fibres (Choi and Kim, 2008).

The results for digestive tract morphometry and breast muscle microstructure in P9 ducks (French Pekin), K2 (bred from wild mallards - Anas platyrhynchos L. and Pekin duck), and KhO1 (hybrid of Khaki Campbell drake and Orpington Fauve duck) after two reproductive seasons will be presented for the first time. The above genetic groups form 3 out of 10 unique flocks of ducks (the only ones in Poland and the world) included in the genetic resources conservation programme. In keeping with the Conservation Programme for Farm Animal Genetic Resources in Poland, breeder flocks of ducks maintained at the Waterfowl Genetic Resources Station are liquidated after two reproductive seasons.

The aim of the study was to determine the differences (morphological and microstructural diversity) between conservation breeds of ducks.

\section{Materials and methods}

The study material consisted of 60 ducks from three genetic groups: P9 (French Pekin), K2 (bred from wild mallards Anas platyrhynchos L. and Pekin duck), and KhO1 (hybrid of Khaki Campbell drake and Orpington Fauve duck) aged 110 weeks, after two reproductive seasons. Before slaughter, birds were penned on litter in a windowless, environmentally controlled confinement building. Ducks were fed ad libitum a complete diet for breeder ducks. The diet contained $18.5 \% \mathrm{CP}$ and $11.1 \mathrm{MJ}$ metabolizable energy per kilogramme. Birds were allowed $24 \mathrm{~h}$ access to water. The study was approved by the Local Ethics Committee in Bydgoszcz (decision no. 8 of 2010).

At the age of 110 weeks, when the birds completed their second reproductive season, 20 birds (10 drakes and
10 ducks) were randomly selected from each of the liquidated $\mathrm{P} 9, \mathrm{~K} 2$, and $\mathrm{KhO} 1$ flocks, and each bird was individually weighed to the nearest $5 \mathrm{~g}$ using an electronic balance (Axis BD 15S, Axis, Gdańsk, Poland). After weighing, the body length of the ducks was determined by tape-measuring with an accuracy of $1 \mathrm{~mm}$ the distance between the first cervical vertebra (atlas) and the posterior superior tuberosity of the ischium.

Following the live measurements, the birds were subjected to on-farm slaughter, defeathering, and evisceration. During the evisceration, the digestive tract and other internal organs of the ducks were separated. The lengths of the duodenum, jejunum, ileum, both caeca, and the colon were tapemeasured with an accuracy of $1 \mathrm{~mm}$. The data concerning total intestinal length (sum of intestinal segments) and body length were used to calculate the intestinal length to body length ratio.

After removing the viscera from the body cavity, proventriculus (without digesta), gizzard (without digesta), liver (without gallbladder), heart, and spleen were separated from each duck and weighed with an accuracy of $0.001 \mathrm{~g}$ on a Medicat M160 electronic balance, and their percentages in pre-slaughter body weight were determined.

For histological analysis, samples of superficial pectoral muscle ( $m$. pectoralis superficialis) were taken from $10 \mathrm{fe}-$ males and 10 males of each genetic group. From each bird aged 110 weeks, three sections $(0.5 \times 0.5 \times 1 \mathrm{~cm}$ each $)$ were taken from the middle part of $m$. pectoralis superficialis, parallel to muscle fibre orientation. The samples were fixed with Sannomiya solution, dehydrated in alcohol and benzene, and embedded in paraffin blocks. The blocks were sectioned with microtome, and sections of $10 \mu \mathrm{m}$ were placed on glass slides and counterstained with hematoxylin and eosin (Burck, 1975) and embedded in Canada balm. The size of muscle tissue microstructural elements was measured using the MultiScanBase v. 13 image analysis system (Computer Scanning System Ltd, Warsaw, Poland). Fibre crosssection area, fibre perimeter and its horizontal $(\mathrm{H})$ and vertical (V) diameter, and thickness of perimysium and endomysium were measured. The determinations were made on three m. pectoralis superficialis preparations per bird. Around 200 muscle fibres were measured in each preparation and 150200 measurements of the connective tissue thickness (perimysium and endomysium) were made. A magnification of $100 \times$ was applied. Based on the data for horizontal and vertical diameters of the muscle fibre, the $\mathrm{H}: \mathrm{V}$ diameter ratio was calculated.

The numerical data were statistically analysed using SAS ver. 9.4 software (SAS Institute Inc., 2014). Arithmetic means and standard error (SE for all groups) were calculated for all the analysed traits. Significant differences between the arithmetic means for body weight and length, morphometric characteristics of the intestine, and breast muscle (m. pectoralis superficialis) microstructure were verified with Tukey's test at $P \leq 0.05$. 
Table 1. Body weight, body, and intestine length and their ratio in spent ducks.

\begin{tabular}{lrrrr}
\hline Genotype & Body weight & \multicolumn{2}{c}{ Length of $(\mathrm{cm})$} & Intestine: \\
\cline { 3 - 4 } & $(\mathrm{g})$ & Body & Intestine & $\begin{array}{r}\text { body } \\
\text { ratio }\end{array}$ \\
\hline P9 & $2981^{\mathrm{a}}$ & $45.6^{\mathrm{a}}$ & $244.8^{\mathrm{a}}$ & $5.4^{\mathrm{a}}$ \\
$\mathrm{K} 2$ & $1744^{\mathrm{b}}$ & $38.9^{\mathrm{c}}$ & $201.7^{\mathrm{c}}$ & $5.2^{\mathrm{a}}$ \\
KhO1 & $1875^{\mathrm{b}}$ & $41.0^{\mathrm{b}}$ & $181.1^{\mathrm{b}}$ & $4.4^{\mathrm{b}}$ \\
Pooled SE & 77.5 & 0.4 & 4.3 & 0.1 \\
\hline
\end{tabular}

a, b, c Indicate significant differences among groups $(P \leq 0.05)$.

\section{Results and discussion}

The average body weight of 110-week old P9 ducks was significantly higher $(P \leq 0.05)$ than that of $\mathrm{K} 2$ and $\mathrm{KhO} 1$ birds (Table 1). Such great differences in the ducks' body weight were due to their different origins. K2 ducks were created from mallards and Pekin ducks with low body weight, which caused a significant reduction in their body weight. KhO1 ducks were developed by crossing a Khaki Campbell male (layer duck) with an Orpington female (general purpose duck), the breeds that have not been improved for meat traits, including high body weight. The body weight of 110week old ducks from the analysed genetic groups was higher compared to the body weight of the ducks of the same genotype evaluated at 7 weeks of age by Kisiel (2003), which may be indicative of the continued growth of the ducks from these genetic groups after 7 weeks of age. Gornowicz and Szukalski (2015), who analysed the body weight of K2 (Mini Duck), P8 (Danish Pekin), P9 (French Pekin), P33 (Polish Pekin), and LsA ducks (English Pekin) under the conservation programme in Poland, also observed that the above genetic groups differed in body weight at the age of 8 weeks. The studied birds, in particular $\mathrm{K} 2$ and $\mathrm{KhO} 1$ ducks, may be useful for production of lighter carcasses, which are increasingly sought by duck meat consumers.

The compared genetic groups of the ducks, which from the 1980s have been selected for conformation and health but not for productive traits, also exhibited significant differences in body length, total intestinal length, and the intestine length to body length ratio, which shows their distinctness and uniqueness in terms of these traits. P9 ducks had significantly $(P \leq 0.05)$ longer body and intestine compared to $\mathrm{K} 2$ and $\mathrm{KhO} 1$ birds. K2 ducks had significantly shorter body length than KhO1 ducks, and KhO1 ducks significantly shorter intestine than K2 ducks. The intestine length to body length ratios were lower than those reported by Wasilewski et al. (2015) for young Pekin ducks. Kokoszyński (2011) observed that four commercial Pekin duck hybrids (Star 53 H.Y., AP54, PP54, and PP45) differed significantly in body weight and length at 7 weeks of age. PP45 and PP54 ducks, which were created by cross-
Table 2. Length of intestine segments in spent ducks.

\begin{tabular}{lrrrrr}
\hline Genotype & \multicolumn{5}{c}{ Length of $(\mathrm{cm})$} \\
\cline { 2 - 6 } & Duodenum & Jejunum & Ileum & Caecum & Colon \\
\hline P9 & $32.2^{\mathrm{a}}$ & $80.3^{\mathrm{a}}$ & $83.0^{\mathrm{a}}$ & $37.1^{\mathrm{a}}$ & 12.2 \\
$\mathrm{~K} 2$ & $27.4^{\mathrm{b}}$ & $65.5^{\mathrm{b}}$ & $68.1^{\mathrm{b}}$ & $30.8^{\mathrm{b}}$ & 9.9 \\
KhO1 & $27.6^{\mathrm{b}}$ & $56.0^{\mathrm{c}}$ & $59.6^{\mathrm{c}}$ & $29.1^{\mathrm{b}}$ & 8.8 \\
Pooled SE & 0.5 & 1.5 & 1.6 & 0.7 & 2.9 \\
\hline
\end{tabular}

a, b, c Indicate significant differences among groups $(P \leq 0.05)$.

ing conserved P44 and P55 ducks, had lower body weight and greater body length compared to Star 53 H.Y. and AP54 birds. In the study by Wasilewski et al. (2015), Pekin SM3 Heavy and AF51 hybrids had longer intestine than the evaluated P9, K2, and KhO1 ducks, which have not been selected for productive traits since the 1980s. In the study by Schmidt et al. (2009) with Ross 708 chickens (modern line) and UIUC (heritage line), jejunum and ileum length was around $20 \%$ longer in Ross 708 chickens than in UIUC chickens, which have not been selected since the 1950s. In another experiment (Watkins et al., 2004), better small intestine development was noted in young mallard ducks than in domesticated Pekin ducks.

The length of intestine segments is presented in Table 2. P9 ducks with the highest body weight at 110 weeks had significantly ( $P \leq 0.05$ ) longer duodenum, jejunum, ileum, and caecum compared to $\mathrm{K} 2$ and KhO1 birds. KhO1 ducks had significantly shorter jejunum and ileum compared to K2 birds. In addition, P9 ducks had longer colon than $\mathrm{K} 2$ and KhO1 birds. However, this difference was not significant. To date, the morphological traits of the intestine have not been determined in ducks after two reproductive seasons. Watkins et al. (2004) report, however, that in Pekin ducks, morphological and functional development of the digestive tract is terminated after 7 weeks of age. An earlier study with young Pekin ducks (6-8 weeks of age) found greater (Jamroz et al., 2001; Wasilewski et al., 2015) lengths of individual intestine segments compared to the analysed ducks after two reproductive seasons.

The present results demonstrate considerable differences between the compared genetic groups of the ducks aged 110 weeks in relative length of the intestine and its segments (Table 3). Lighter $\mathrm{K} 2$ and $\mathrm{KhO} 1$ duck had relatively greater total intestine length and length of its segments compared to P9 ducks. Furthermore, K2 ducks with the lowest body weight had greater relative length $\left(\mathrm{cm} 100^{-1} \mathrm{gBW}\right)$ of jejunum, ileum, caecum, colon, and total intestine compared to KhO1 birds. The highest relative length of the intestine and its segments was calculated for K2 ducks, and the lowest for the heaviest P9 ducks. The results obtained for the relative length of the intestine and its segments in the studied ducks were higher than the values reported for 7-week old Pekin ducks (SM3 Heavy hybrid) by Stęczny et al. (2017). 
Table 3. Relative length of intestine segments in spent ducks.

\begin{tabular}{lrrrrrr}
\hline \multirow{2}{*}{ Genotype } & \multicolumn{6}{c}{ Length of $(\mathrm{cm}) 100^{-1} \mathrm{gBW}$} \\
\cline { 2 - 7 } & Duodenum & Jejunum & Ileum & Caecum & Colon & Total \\
\hline P9 & $1.08^{\mathrm{b}}$ & $2.69^{\mathrm{b}}$ & $2.78^{\mathrm{c}}$ & $1.24^{\mathrm{c}}$ & $0.41^{\mathrm{c}}$ & $8.21^{\mathrm{c}}$ \\
$\mathrm{K} 2$ & $1.57^{\mathrm{a}}$ & $3.76^{\mathrm{a}}$ & $3.90^{\mathrm{a}}$ & $1.77^{\mathrm{a}}$ & $0.57^{\mathrm{a}}$ & $11.56^{\mathrm{a}}$ \\
KhO1 & $1.47^{\mathrm{a}}$ & $2.99^{\mathrm{c}}$ & $3.17^{\mathrm{b}}$ & $1.55^{\mathrm{b}}$ & $0.47^{\mathrm{b}}$ & $9.65^{\mathrm{b}}$ \\
Pooled SE & 0.03 & 0.08 & 0.08 & 0.04 & 0.04 & 0.16 \\
\hline
\end{tabular}

a, b, Indicate significant diffgerences among groups $(P \leq 0.05)$.

Table 4. Weight and proportion (\%) in the body weight of main internal organs in spent ducks.

\begin{tabular}{lcccrr}
\hline Genotype & Liver & Heart & $\begin{array}{r}\text { Proventri- } \\
\text { culus }\end{array}$ & Gizzard & Spleen \\
\hline \multicolumn{5}{c}{ Weight of $(\mathrm{g})$} \\
\hline P9 & $62.6^{\mathrm{a}}$ & $17.9^{\mathrm{a}}$ & 8.2 & $68.5^{\mathrm{a}}$ & 1.1 \\
$\mathrm{~K} 2$ & $29.0^{\mathrm{b}}$ & $11.2^{\mathrm{b}}$ & 6.0 & $45.3^{\mathrm{b}}$ & 1.0 \\
KhO1 & $34.0^{\mathrm{b}}$ & $12.0^{\mathrm{b}}$ & 7.0 & $57.8^{\mathrm{c}}$ & 1.0 \\
Pooled SE & 2.8 & 0.5 & 0.3 & 0.3 & 0.1 \\
\hline \multicolumn{7}{c}{ Proportion (\%) in body weight } \\
\hline P9 & 2.1 & 0.60 & $0.28^{\mathrm{b}}$ & 2.3 & $0.04^{\mathrm{b}}$ \\
K2 & 1.7 & 0.64 & $0.34^{\mathrm{b}}$ & 2.6 & $0.06^{\mathrm{a}}$ \\
KhO1 & 1.8 & 0.64 & $0.37^{\mathrm{a}}$ & 3.1 & $0.05^{\mathrm{a}}$ \\
Pooled SE & 0.07 & 0.01 & 0.01 & 0.07 & 0.01 \\
\hline
\end{tabular}

a, b, Indicate significant differences among groups $(P \leq 0.05)$.

The different genetic origin of the analysed ducks had a significant $(P \leq 0.05)$ effect on the heart, gizzard, and liver weight. P9 ducks had significantly heavier hearts, gizzards, and livers compared to $\mathrm{K} 2$ and $\mathrm{KhO} 1$ ducks. In addition, KhO1 ducks had significantly higher gizzard weight than K2 birds (Table 4). The compared duck groups did not differ in proventriculus and spleen weight.

The percentage of heart, gizzard, and liver in the body of the ducks of different genetic origin was similar, with no significant differences (Table 4). KhO1 ducks had a significantly higher percentage of proventriculus, and P9 ducks a significantly lower percentage of spleen compared to the other duck groups under study. Makram et al. (2017) observed significant differences in gizzard and liver percentage $(P \leq 0.01)$ and in heart percentage $(P \leq 0.05)$ in Sudani, Muscovy, and Pekin ducks from parent flocks at marketing age. The heart and liver percentage of Muscovy and Pekin ducks investigated by Makram et al. (2017) was higher than in $\mathrm{P} 9, \mathrm{~K} 2$, and $\mathrm{KhO} 1$ ducks from this experiment. In another study (Wasilewski et al., 2015), liver and heart percentage was lower and gizzard percentage higher in 7-week old Pekin ducks compared to the ducks aged 110 weeks. Bartyzel et al. (2005) noted higher heart percentage (males -
$0.76 \%$, females $-0.69 \%$ ) in wild mallards weighing $1320 \mathrm{~g}$ (males) and $1250 \mathrm{~g}$ (females) compared to Pekin males $(\mathrm{BW}=3128 \mathrm{~g}$, heart $=0.62 \%)$ and females $(\mathrm{BW}=3143 \mathrm{~g}$, heart $=0.60 \%$ ). Oh et al. (2015) reported similar spleen percentage in the bodies of 6-week old Pekin ducks compared to the studied ducks at 110 weeks of age.

The compared genetic groups of the ducks at the age of 110 weeks did not differ significantly in the microstructural characteristics of $m$. pectoralis superficialis, except for thickness of perimysium (connective tissue surrounding a muscle fibre bundle) and endomysium (connective tissue surrounding a single muscle fibre) (Table 5).

The muscle fibres of the lighter $\mathrm{K} 2$ and $\mathrm{KhO} 1$ ducks were characterized by smaller area and diameter $(P>0.05)$ but significantly greater perimysium (K2 ducks) and endomysium (K2 and Kh01 ducks) thickness compared to P9 birds. The studied microstructural characteristics largely determine meat tenderness, which is considered the most important characteristic influencing its consumption. Hašcik et al. (2006) reported smaller muscle fibre diameter of $m$. pectoralis major in the wild duck $(21.8 \mu \mathrm{m})$ weighing $1026.4 \mathrm{~g}$ compared to the domestic duck $(28.2 \mu \mathrm{m})$ weighing $2107.0 \mathrm{~g}$, which supports the present results. In the study by Kokoszyński (2011), Star 53 HY ducks, characterized by faster growth rate and higher body weight at 8 weeks of age, had greater diameter of white and red muscle fibres compared to the slow-growing and lighter PP45 and PP54 ducks. However, Bernacki et al. (2008) did not observe significant differences between 7-week old Star 63, PP54 (Pekin hybrids), and CaA15 (Dworka - crosses of Cayuga drake and Pekin female) ducks of different body weight in terms of the muscle fibre diameter of the pectoralis superficialis muscle. In turn, Witkiewicz et al. (2004) noted that selection for increased muscling in A44 and P66 breeding ducks negatively affected the microstructure of their breast muscles, because P33 and K2 genetic resources ducks unimproved for meat traits had more red muscle fibres and lower diameter of white and red fibres, which is more favourable for the consumers of duck meat. Earlier findings (Muhlisin et al., 2013; Wasilewski, 2018) show that native duck carcasses and meat are highly suitable for producing quality and regional food 
Table 5. Microstructural characteristics of $m$. pectoralis superficialis in spent ducks.

\begin{tabular}{|c|c|c|c|c|c|c|c|}
\hline Genotype & $\begin{array}{r}\text { Fibre } \\
\text { cross } \\
\text { section } \\
\text { area } \\
\left(\mu \mathrm{m}^{2}\right)\end{array}$ & $\begin{array}{r}\text { Fibre } \\
\text { perimeter } \\
(\mu \mathrm{m})\end{array}$ & $\begin{array}{r}\text { Fibre } \\
\text { diameter } \\
\mathrm{H} \\
(\mu \mathrm{m})\end{array}$ & $\begin{array}{r}\text { Fibre } \\
\text { diameter } \\
\mathrm{V} \\
(\mu \mathrm{m})\end{array}$ & $\begin{array}{r}\mathrm{H}: \mathrm{V} \\
\text { diameter } \\
\text { ratio } \\
(x)\end{array}$ & $\begin{array}{r}\text { Perimy- } \\
\text { sium } \\
\text { thickness } \\
(\mu \mathrm{m})\end{array}$ & $\begin{array}{r}\text { Endomy- } \\
\text { sium } \\
\text { thickness } \\
(\mu \mathrm{m})\end{array}$ \\
\hline P9 & 125.8 & 47.6 & 12.9 & 11.5 & 1.1 & $4.2^{\mathrm{b}}$ & $1.0^{\mathrm{b}}$ \\
\hline $\mathrm{K} 2$ & 112.7 & 44.3 & 11.9 & 10.9 & 1.1 & $5.9^{\mathrm{a}}$ & $1.4^{\mathrm{a}}$ \\
\hline KhO1 & 90.8 & 40.1 & 11.0 & 9.4 & 1.2 & $5.1^{\mathrm{b}}$ & $1.5^{\mathrm{a}}$ \\
\hline Pooled SE & 12.5 & 2.4 & 0.7 & 0.6 & 0.01 & 0.3 & 0.1 \\
\hline
\end{tabular}

${ }^{\mathrm{a}, \mathrm{b}}$ Indicate significant differences among groups $(P \leq 0.05)$.

products that are safe and wholesome due to their nutritive and dietetic attributes.

\section{Conclusions}

It is concluded that the compared genetic groups of the ducks of different origin at the age of 110 weeks differed significantly in body weight, body length, and length of the intestine and its segments. Duck genotype had a significant effect on heart, gizzard, and liver weight, and on proventriculus and spleen percentage in the body.

The different origin of the birds had no influence on the microstructural characteristics of the superficial pectoral muscle except for perimysium and endomysium thickness. The breast muscles of $\mathrm{K} 2$ and $\mathrm{KhO} 1$ ducks had smaller area and muscle fibre diameter as well as greater endomysium and perimysium thickness compared to P9 birds.

Data availability. The data are available from the corresponding author upon request.

Author contributions. DK wrote the manuscript and developed the methodology, made the description of the methods used to determine the studied traits for methodology and laboratory analyses, performed the calculations, and assumed primary responsibility for the final content, MS made the description of the methods used to determine the studied traits for methodology, performed the research, and analysed the data, and ZB read and made the corrections, wrote the manuscript and developed the methodology, and made the description of the methods used to determine the studied traits for methodology and laboratory analyses. MS performed the research, made laboratory analyses, and analysed the data, and MK, MS, JZK, and KS made the description of the methods used to determine the studied traits for methodology and laboratory analyses, and performed the research. Finally, all the authors commented on the early and final responses to the manuscript.

Competing interests. The authors declare that there is no conflict of interest.
Acknowledgements. This study was realized from statutory research fund BS-13/2009 assigned by the Polish Ministry of Science and Higher Education.

Edited by: Steffen Maak

Reviewed by: Emilia Mróz and one anonymous referee

\section{References}

Applegate, T. J., Karcher, D. M., and Liburn, M. S.: Comparative development of the small intestine in the turkey poult and Pekin duckling, Poult. Sci., 84, 426-431, 2005.

Bartyzel, B. J., Karbowicz, M., and Bartyzel, I. A.: Comparison of body and heart size between the Mallard and Pekin duck, Vet. Zootech., 29, 22-25, 2005.

Bernacki, Z., Kokoszyński, D., and Mallek, T.: Evaluation of selected meat traits in seven-week-old duck broilers, Anim. Sci. Pap. Rep., 26, 165-174, 2008.

Burck, H. C.: Histological technology, Państwowy Zakład Wydawnictw Lekarskich, Warsaw, 1975.

Choi, Y. M. and Kim, B. C.: Muscle fibre characteristics, myofibrillar protein isoforms, and meat quality, Livest. Sci., 122, 105-118, 2008.

Elminowska-Wenda, G. and Szpinda, M.: Meat of slaughter animals, histological structure and chemical composition, in: Meat - the basics of science and technology, edited by: Pisula, A. and Pospiech, E., SGGW Warszawa, 120-132, 2011.

Gornowicz, E. and Szukalski, G.: Duck meat - selected issues of domestic production, Polish Poultry, 8, 2-10, 2015.

Hassouna, E. M. A.: Some anatomical and morphometrical studies on the intestinal tract of chicken, duck, goose, turkey, pigeon, dove, quail, sparrow, heron, jackdaw, hoopoe, kestrel and owl, Assiut Vet. Med. J., 44, 47-78, 2001.

Hašcík, P., Kulišek, V., and Makovický, P.: Histological analysis of muscle of wild and domestic ducks, Acta fytotechn. zootechn., 9, 110-113, 2006.

Jamroz, D., Jakobsen, K., Orda, J., Skorupińska, J., and Wiliczkiewicz, A.: Development of the gastrointestinal tract and digestibility of dietary fibre and amino acids in young chickens, ducks and geese fed diets with high amounts of barley, Comp. Biochem. Physiol., 130A, 643-652, 2001.

Kasperska, D., Kokoszyński, D., Korytkowska, H., and Mistrzak, M.: Effect of age and sex on digestive tract morphometry of 
guinea fowl (Numida meleagris L.), Folia Biol.-Kraków, 60, 4549, 2012.

King, D. E., Asem, E. K., and Adeola, O.: Ontogenetic development of intestinal digestive functions in White Pekin ducks., J. Nutr., 130, 57-62, 2000.

Kisiel, T.: Differentiation of ducks conservative groups in terms of reproductive and meat traits, Dissertation, Waterfowl Genetic Resources Station, Kołuda Wielka Experimental Station of National Research Institute of Animal Production, Dworzyska near Poznan, Poland, 2003.

Kissling, K. H.: Muscle structure and function in the goose, quail, pheasant, guinea hen, and chicken, Comp. Biochem. Physiol., 57B, 137-144, 1977.

Kokoszyński, D.: Evaluation of meat traits in commercial crossbreds of Pekin type ducks, edited by: UTP Bydgoszcz, Habilitation, 147, 1-113, 2011.

Langenfeld, M. S.: Chicken anatomy, edited by: PWN Kraków, Poland, 1992.

Makram, A., Galal, A., and El-Attar, A. H.: Effects of strain and sex on carcass parameters for three duck strains, Proceedings of the 7th International Conference of Sustainable Agricultural Development, Egypt, 248-256, 2017.

Muhlisin, M., Kim, D. S., Song, Y. R., Kim, H. R., Kwon, H. J., An, B. K., Kang, C. W., Kim, H. K., and Lee, S. K.: Comparison of meat characteristics between Korean native duck and imported commercial duck raised under identical rearing and feeding condition, Korean J. Food Sci. Anim. Res., 33, 89-95, 2013.

Oh, S. T., Zheng, L., Kwon, H. J., Choo, Y. K., Lee, K. W., Kang, C. W., and An, B. K.: Effects of dietary fermented Chlorella vulgaris (CBT) on growth performance, relative organ weights, cecal microflora, tibia bone characteristics, and meat qualities in Pekin ducks, Asian Australas. J. Anim., 28, 95-101, 2015.
SAS Institute Inc. SAS/STAT User's Guide, version 9.4., SAS Institute Inc, Cary, NC, USA, 2014.

Schmidt, C. J., Persia, M. E., Feierstein, E., Kingham, B., and Saylor, W. W.: Comparison of a modern broiler line and a heritage line unselected since the 1950s, Poultry Sci., 88, 2610-2619, 2009.

Stęczny, K., Kokoszyński, D., Bernacki, Z., Wasilewski, R., and Saleh, M.: Growth performance, body measurements, carcass composition and some internal organ characteristics in young Pekin ducks, S. Afr. J. Anim. Sci., 47, 399-406, 2017.

Szczepańczyk, E., Kalisińska, E., Ligocki, M., and Bartyzel, B.: Morphometry of esophagus and gut in bean goose Anser fabalis, Zoologica Poloniae, 45, 37-46, 2000.

Watkins, E. J., Butler, P. J., and Kenyon, B. P.: Posthatch growth of the digestive system in wild and domesticated ducks, Brit. Poultry Sci., 45, 331-341, 2004.

Wasilewski, R.: Analysis of meat traits in some groups of Pekin ducks from genetic reserve flocks, Dissertation, UTP Bydgoszcz, Bydgoszcz, Poland, 2018.

Wasilewski, R., Kokoszyński, D., Mieczkowska, A., Bernacki, Z. and Górska, A.: Structure of the digestive system of ducks depending on sex and genetic background, Acta Vet. Brno, 84, 153$158,2015$.

Witkiewicz, K., Kontecka, H., Książkiewicz, J., Szwaczkowski, T., and Perz, W.: Carcass composition and breast microstructure in selected vs. non-selected ducks, Anim. Sci. Pap. Rep., 22, 65-73, 2004. 